\title{
33. CARBOHYDRATE RESIDUES IN LEG 64 CORE SAMPLES 1
}

\author{
Frederick M. Swain, University of Minnesota, Minneapolis, Minnesota and University of Delaware, Newark, Delaware \\ and \\ Judy M. Bratt, University of Minnesota, Minneapolis, Minnesota
}

\begin{abstract}
We analyzed 10 core samples of Pleistocene and Pliocene sediment for residual carbohydrates. All yielded positive results for total carbohydrates and acid-extractable glucose. We also detected galactose, mannose, arabinose, xylose, and traces of ribose and fucose in the Pleistocene samples. In the Pliocene samples we found only rare mannose. Only one Pleistocene sample yielded measurable cellulose and amylose.
\end{abstract}

\section{INTRODUCTION}

We analyzed parts of frozen core samples from Holes $474,474 \mathrm{~A}$, and 476 for residual carbohydrates. The samples were studied for total carbohydrates, water-soluble monosaccharides, acid-soluble monosaccharides, and starch and cellulose.

\section{METHOD}

We analyzed total carbohydrates by a modified phenol-sulfuric acid method (DuBois et al., 1956; Swain, 1966). The weight of the samples ranged from 2.4 to $7.9 \mathrm{~g}$.

Additional samples ranging from 8.5 to $28.3 \mathrm{~g}$ were extracted with boiling water under reflux conditions for 24 hours, followed by extraction with $0.5 \mathrm{~N}$ sulfuric acid for 24 hours. We further analyzed the two extracts for free sugars and polysaccharide residues in the water extracts and polymeric sugars in the acid extracts (Swain, 1970). Monosaccharides were analyzed by gas-liquid chromatography of trimethylsilyl ether derivatives of the constituent sugars. We determined the presence of $\beta$-D-glucose and $\beta$-D-galactose by enzymatic methods, using glucose oxidase and galactose dehydrogenase procedures (Swain and Bratt, 1972). We tested for cellulose and starch, using cellulase and amylase enzyme preparations, respectively (Table 1).

\section{RESULTS}

The total carbohydrates in early Pliocene-to-latePleistocene sediment range from 0.113 to $3.28 \mu \mathrm{g} / \mathrm{g}$ and average $0.88 \mu \mathrm{g} / \mathrm{g}$ (Table 1). The older samples are generally lower in total carbohydrate, but the decrease with increasing age is not uniform. The test for total carbohydrates detected only sugars that bear reducing groups (i.e., free-aldehyde or ketone groups). Nonreducing sugars lacking such groups were not detected by the phenol-sulfuric acid method.

The distribution of free monosaccharides in these samples is shown in Table 1. The values are small, generally less than $10 \mu \mathrm{g} / \mathrm{g}$. Glucose is the most common free sugar in all the samples and the only one detected in most. The uppermost early Pleistocene sample yielded small amounts of free mannose, xylose, and fucose-in addition to glucose-but no galactose. This assemblage of free sugars suggests a near-shore source of land-

\footnotetext{
${ }^{1}$ Curray, J. R., Moore, D. G., et al., Init. Repts. DSDP, 64: Washington (U.S. Govt. Printing Office).
}

derived vegetation and larger algae. The source of free sugars in the sediment is probably from the degradation, in situ, of parts of the incorporated polymeric sugars. The small quantity of chromatographically determined free galactose in the early Pliocene (Unit III) was not confirmed enzymatically, which suggests that all the galactose in this sample is racemic.

The acid-extractable monosaccharides of the Leg 64 samples are shown in Table 1 . The level of polymeric monosaccharides in several of the samples is higher than in most other offshore oceanic sediment samples (Swain and Bratt, 1972, 1978). Those showing relatively high content and diversity of polymeric sugars are from the Pleistocene epoch. The Pliocene samples have a much lower content and variety of such sugars. The constituent sugars in the Pleistocene samples indicate a variety of sources, including terrestrial plants, marine algae, and bacteria.

Only Sample 476-7-6, 117-123 cm (early Pleistocene; Unit II) yielded measurable amounts of polysaccharides. It contained $1.73 \mu \mathrm{g} / \mathrm{g}$ of glucose equivalent, representing cellulose, and $0.17 \mu \mathrm{g} / \mathrm{g}$ of glucose equivalent, representing amylose. No reason for the preservation of polysaccharides in this sample, as compared to several other richer samples, is apparent.

All but the early Pleistocene sample (476-11-4, 126$131 \mathrm{~cm}$ ) have total reducing carbohydrates in excess of the characterizable free-plus polymeric carbohydrates. The remainder of the total carbohydrates in most of the samples is probably represented by furfurals and related degradation products of carbohydrates. The results from the Pleistocene sample, in which the characterizable sugar exceeds the total reducing sugars, suggest that some nonreducing polymeric carbohydrates such as the oligosaccharide $\alpha, \alpha$-trehalose may be present. The logical source of this oligosaccharide may be seaweed (Pigman, 1957).

\section{CONCLUSION}

As in Deep Sea Drilling Project samples previously analyzed, glucose is the most common carbohydrate in the deep sea sediment. Galactose is less common than in most other DSDP samples. Compared to other DSDP 
Table 1. Carbohydrates, free sugars, and acid-extractable sugar, Leg 64 Holes 474, 474A, and 476.

\begin{tabular}{|c|c|c|c|c|c|c|c|c|c|c|c|c|}
\hline $\begin{array}{c}\text { Sample } \\
\text { (interval in } \mathrm{cm} \text { ) }\end{array}$ & Age & $\begin{array}{l}\text { Lithologic } \\
\text { Unit }\end{array}$ & $\begin{array}{c}\text { Total } \\
\text { Carbohydrates } \\
(\mu g / g)\end{array}$ & Glucose & Galactose & Mannose & Arabinose & Xylose & Ribose & Fucose & $\Sigma$ & Sediment Description \\
\hline $474-2-3,140-145$ & Late Pleistocene & & 3.28 & $(0.358)^{\mathrm{a}}$ & $(0.703)^{\mathrm{a}}$ & $0(0.514)$ & $O(0.188)$ & $0(0.517)$ & $0(0.02)$ & 0 & $(2.30)$ & $\begin{array}{l}\text { Hemipelagic diatom/nannofossil } \\
\text { ooze and mud }\end{array}$ \\
\hline $476-3-4,140-145$ & Late Pleistocene & & 2.007 & $(0.004)^{\mathrm{a}}$ & $0^{\mathrm{a}}$ & 0 & 0 & 0 & 0 & 0 & $(0.004)$ & $\begin{array}{l}\text { Hemipelagic ooze, brown diatom/ } \\
\text { nannofossil ooze, and mud }\end{array}$ \\
\hline $474-6-5,20-30$ & Early Pleistocene & 1 & 0.869 & $(0.033)^{\mathrm{a}}$ & 0 & 0.0008 & 0 & 0.004 & 0 & 0.007 & 0.154 & $\begin{array}{l}\text { Hemipelagic diatom/nannofossil } \\
\text { ooze and mud }\end{array}$ \\
\hline $476-7-6,117-123$ & Early Pleistocene & & 0.665 & $(0.03)$ & $0^{\mathrm{a}}$ & 0 & 0 & 0 & 0 & 0 & $(0.03)$ & $\begin{array}{l}\text { Hemipelagic diatom/nannofossil } \\
\text { ooze and mud }\end{array}$ \\
\hline $476-11-4,126-131$ & Early Pleistocene & III & 0.169 & $(0.198)^{\mathrm{a}}$ & $0(0.174)^{\mathrm{a}}$ & $0(0.117)$ & 0 & 0 & 0 & 0 & $(0.754)$ & Hemipelagic mud \\
\hline $474 A-7-2,121-131$ & Early Pleistocene & III & 0.530 & $(0.002)^{\mathrm{a}}$ & 0 & 0 & $\theta$ & 0 & 0 & 0 & $(0.002)$ & $\begin{array}{l}\text { Mud, turbidites, gray olive } \\
\text { siltstone, and claystone }\end{array}$ \\
\hline $476-15-2,110-117$ & Late Pliocene & II & 0.394 & $(0.001)^{\mathrm{a}}$ & 0 & 0 & 0 & 0 & 0 & 0 & $(0.001)$ & Hemipelagic mud \\
\hline $474 \mathrm{~A}-32-2,134-149$ & Late Pliocene & IV & 0.601 & $(0.001)^{\mathrm{a}}$ & 0 & 0 & 0 & 0 & 0 & 0 & $(0.001)$ & Gray turbidite siltstone \\
\hline $476-19-1,135-140$ & Early Pliocene & III & 0.113 & $(0.002)^{\mathrm{a}}$ & (a) & 0.001 & 0 & 0 & 0 & 0 & 0.003 & $\begin{array}{l}\text { Muddy diatom ooze with turbidites, } \\
\text { vitric ash, and glauconite }\end{array}$ \\
\hline $474 \mathrm{~A}-41-3,125-131$ & Early Pliocene & $\mathrm{v}$ & 0.252 & $\left({ }^{a}\right)$ & $O\left(^{(a)}\right.$ & 0 & 0 & 0 & 0 & 0 & (tr) & $\begin{array}{l}\text { Claystone between dolerite } \\
\text { sills or flows }\end{array}$ \\
\hline
\end{tabular}

Note: Values in parentheses are for acid-extractable sugars; $t \mathrm{tr}=$ trace.

Note: Values in parentheses are for acid-extractable sugars; $\mathrm{tr}=$ trace.
a Presence of $\beta$-D-glucose and $\beta$-D-galactose confirmed by enzymatic tests.

samples, those in our study may reflect a greater contribution from land-derived plants and less from planktonic organisms.

\section{ACKNOWLEDGMENTS}

The facilities of the Department of Biochemistry, University of Minnesota were used for gas chromatographic analyses. The manuscript was reviewed by B. R. T. Simoneit and J. F. Wehmiller, who made several valuable suggestions.

\section{REFERENCES}

DuBois, M., Gilles, K. A., Hamilton, J. D., et al., 1956. Colorimetric method for determination of sugars and related substances. Anal. Chem., 28:350-356.
Pigman, W. (Ed.), 1957. The Carbohydrates: New York (Academic). Swain, F. M., 1966. Distribution of some organic substances in Paleozoic rocks of central Pennsylvania. In Given, P. H. (Ed.), Advances in Chemistry Series 55: Washington (American Chemical Society), pp. 1-21.

1970. Non-Marine Organic Geochemistry: Cambridge (Cambridge University Press).

Swain, F. M., and Bratt, J. M., 1972. Comparative carbohydrate geochemistry of bay, salt marsh, and deep gulf sediments. In von Gaertner, H. R., and Wehner, H. (Eds.), Advances in Organic Geochemistry: 1972: Oxford (Pergamon), pp. 415-425.

1978. Carbohydrate residues in Leg 64 core samples. In Benson, W. E., Sheridan, R. E., et al., Init. Repts. DSDP, 44: Washington (U.S. Govt. Printing Office), 653-654. 